\title{
Cleaning Up
}

\section{Dear Reader,}

$\mathrm{NO}_{\mathrm{x}}$ alarm in Germany's conurbations. In June, the EU Commission initiated infringement proceedings against Germany because limit values for air quality had been exceeded too frequently. In July, the federal state of Hesse lost a court case brought by the German environmental protection NGO "Deutsche Umwelthilfe" at the Administrative Court in Darmstadt because it had taken insufficient measures to comply with limit values for nitrogen oxides in the towns of Limburg and Offenbach. There is clearly a need for action.

According to the German Advisory Council on the Environment (SRU), nitrogen oxides in ambient air have a detrimental impact on human health and, together with ammonia, form hazardous particulate matter and contribute to the formation of ground-level ozone. The SRU experts also assert that the excessive release of reactive nitrogen compounds into the environment considerably reduces biodiversity.

These problems should be quickly addressed and solved by creating an integrated clean-air plan across all sectors of industry. In this plan, polluters such as diesel vehicles must not be used as a scapegoat. According to studies by Bosch, diesel cars produce only $10 \%$ of $\mathrm{NO}_{\mathrm{x}}$ emissions in Germany. Far greater factors outside road traffic are energy production (27\%) and households (11\%), according to figures from the German Association of the Automotive Industry (VDA).

It is true that environmental politicians have been dealing with individual aspects of $\mathrm{NO}_{\mathrm{x}}$ for decades now. But there is still the impression that federal, regional and local authorities are simply passing the buck to one another. And the
VDA argues with environmental organisations about who has the more correct data. Instead of this, there must be an awareness of the bigger picture. What is needed is a coordinated strategy, in which transportation must make its contribution. As recommended by the SRU, the EU emissions standards should be further developed not only for cars, trucks and mobile machines but also for maritime shipping - but in moderation.

We hope that the whole business will not become contra-productive. Improvements in $\mathrm{NO}_{\mathrm{x}}$ mean that $\mathrm{CO}_{2}$ emissions get worse. And that would hit precisely the wrong target, the passenger car with a diesel engine, without which $\mathrm{CO}_{2}$ emissions would already be $10 \%$ higher today. The ATZ editorial team would be glad to discuss with you this problem and other matters on the IAA fair in Hall 4.1, booth $\mathrm{C} 11$ of Springer Fachmedien.

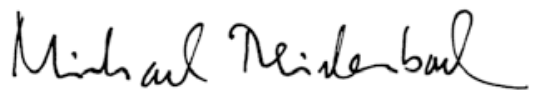

Dipl.-Ing. Michael Reichenbach Deputy Editor in Chief

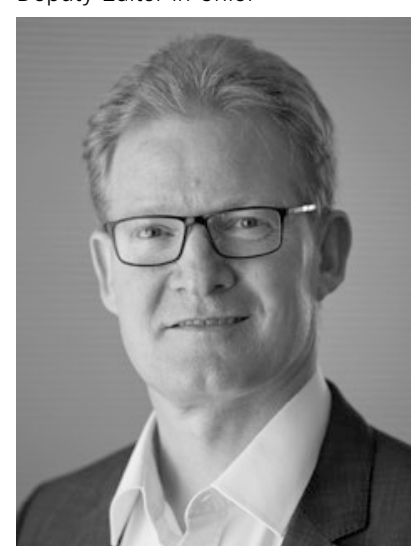

